\title{
Impact of nutritional status at the onset of elementary school on academic aptitude test achievement at the end of high school in a multicausal approach
}

\author{
Daniza M. Ivanovic ${ }^{1,2,3 *}$, María del Pilar N. Rodríguez ${ }^{1}$, Hernán T. Pérez ${ }^{1}$, Jorge A. Alvear ${ }^{1}$, \\ Atilio F. Almagià ${ }^{4}$, Triana D. Toro ${ }^{4}$, María Soledad C. Urrutia ${ }^{5}$, Arturo L. Cruz ${ }^{2,3}$ and Rodolfo M. Ivanovic ${ }^{1}$ \\ ${ }^{1}$ Institute of Nutrition and Food Technology (INTA), University of Chile, Santiago, Chile \\ ${ }^{2}$ School of Public Health, Loma Linda University, California, USA \\ ${ }^{3}$ Adventist University of Chile, Chillán, Chile \\ ${ }^{4}$ Catholic University of Valparaíso, Valparaíso, Chile \\ ${ }^{5}$ PAHO/WHO, Washington, DC, USA
}

(Received 28 March 2008 - Revised 3 October 2008 - Accepted 13 October 2008 - First published online 13 January 2009)

\begin{abstract}
Like in many other countries, few investigations have been carried out in Chile to measure the long-term effects of nutritional status at an early age on scholastic achievement in a multicausal approach. The objectives of the present study were to describe the impact of nutritional, intellectual, family, educational and socio-economic variables at the onset of elementary school in 1987 that may affect achievement on the academic aptitude test (AAT) taken in 1998 at the end of high school, and to quantify the impact of these independent variables on the AAT. The present study comprises two cross-sectional stages: in 1987, a representative sample of 813 elementary school first-grader Chilean children from the Metropolitan Region was randomly chosen; in 1998, 12 years later, 632 school-age children were located and only 351 of them graduated from high school and, from these, 260 students took the AAT. In 1987 nutritional status was assessed through anthropometric parameters, intellectual ability by the Raven's Progressive Matrices Test, scholastic achievement through Spanish language and mathematics tests, and socio-economic status using Graffar's modified scale; family variables were also recorded. Maternal schooling, scholastic achievement, intellectual ability and head circumference-for-age $z$-score (anthropometric indicator of both nutritional background and brain development) all in 1987 were the independent variables with the greatest explanatory power for AAT variance in $1998\left(r^{2}\right.$ 0.402). These results provide a foundation to identify the risk factors at an early age that affect AAT scores and should be useful to improve nutritional and educational policies.
\end{abstract}

Child nutrition: Intelligence: Education

Among the main national priorities in Chile are the decrease of extreme poverty and improvement in the quality of education. However, this depends on the child, his family and factors related to the educational system that affect scholastic achievement and desertion $^{(1-7)}$. Like in many other countries, few investigations have been carried out in Chile to measure the long-term effects of nutritional status at an early age on scholastic achievement because most of the research has been focused on the socio-economic determinants of the learning process. In addition, research related with a global approach of this in follow-up studies is scant ${ }^{(5,8-12)}$. Schoolage children of the poor strata attend mainly public (state) schools and achieve significantly lower results than their peers from the medium or high socio-economic strata both in scholastic achievement and intelligence tests. The unsatisfactory results can be explained by deficient environmental conditions such as low parental income and schooling and precarious quality of housing with inadequate sewerage and water supply systems, situations that do not encourage learning and intellectual development ${ }^{(5,11-17)}$.

In Chilean school-age children, nutritional status has been positively and significantly correlated with socio-economic conditions, scholastic achievement and intelligence, especially with those indicators of past nutrition, such as weight, height and head circumference $(\mathrm{HC})^{(4,5,10,11,13,15,17-21)}$. In this context, $\mathrm{HC}$ is the most relevant index associated with learning and intelligence. Children with a suboptimal HC graduating from high school have twice the probability of failing the academic aptitude test (AAT) for university admission. Even more, educational selectivity correlates with $\mathrm{HC}$ and not with weight and height; this results in a higher desertion rate among children with suboptimal $\mathrm{HC}^{(7,22)}$. $\mathrm{HC}$ is an anthropometric indicator of both nutritional background and brain development and constitutes the most sensitive physical index of undernutrition at an early age ${ }^{(3,4,8,9,20,22-25)}$. Furthermore, it has been found by several investigators to be positively and significantly correlated

Abbreviations: AAT, academic aptitude test; HC, head circumference; IA, intellectual ability; IQ, intelligence quotient; Z-H, height-for-age $z$-score; LA, Spanish language test; MA, mathematics test; p, percentile; Q, quartile; SA, scholastic achievement; SES, socio-economic stratum; Z-HC, head-circumference-for-age $z$-score; Z-W, weight-for-age $z$-score; Z-W/H, weight-for-height $z$-score.

* Corresponding author: Professor Daniza M. Ivanovic, fax +56 2214030, email daniza@inta.cl; inta8@abello.dic.uchile.cl 
with intelligence ${ }^{(3,4,8-10,13,25-45)}$. Some of these studies confirmed that head size at age 1 year is a good predictor of later intelligence $\mathrm{e}^{(30-35,38,39,46)}$.

Long-term studies indicate a positive and significant correlation between growth indicators, particularly weight, height and $\mathrm{HC}$, and intellectual abilities of children $^{(3-5,8-10,13,25,27,30,34-36,38,42,45)}$. On the other hand, intelligence has been described as the most important variable that explains scholastic achievement and AAT variances in both sexes $^{(5,6,8-10,47)}$. A comparative study of high school graduates of the low socio-economic stratum (SES), with and without undernutrition in the first year of life, emphasised that maternal schooling, child brain volume and undernutrition in the first year of life were the independent variables with the greatest explanatory power on intelligence quotient (IQ), but only IQ explained scholastic achievement variance. The IQ, corpus callosum length, anteroposterior brain diameter and maternal schooling have been identified as the independent variables with the greatest explanatory power in AAT variance $^{(9)}$.

The AAT, the baccalaureate examination for university admission with national coverage, is the most relevant educational achievement measurement that reflects the result of the educational process along the school years. Cross-sectional studies carried out by us revealed that students with high AAT scores had IQ, parental IQ, scholastic achievement, brain volume, HC, maternal schooling, head of household occupation and quality of housing significantly higher than their peers that achieved the lowest AAT scores, of whom $19 \%$ had been severely malnourished in the first year of life. Logistic regression analysis revealed that student IQ is the best predictor of AAT score and the OR (1.252) implies that when the IQ score increases by one point, the probability of a high AAT score increases by $25 \cdot 2 \%^{(6)}$.

Taking into consideration the previous discussion, the aims of this follow-up study were: (i) to describe the nutritional, intellectual, family, educational and socio-economic characteristics of the children on admission to elementary school in 1987 that may affect outcomes at the end of the high school period, 12 years later, in 1998, when all have to take the AAT for university admission; (ii) the quantification of the impact of these independent variables on AAT scores; (iii) to learn which risk factors, when present at an early age, may predict outcomes at the AAT, with the purpose of suggesting steps to improve the learning process, considering that for most of high school graduates this test has considerable importance for their professional future.

\section{Materials and methods}

\section{Study population and sample}

The target population, 75138 children, included all school-age children who were enrolled in the first grade of elementary schools in the Metropolitan Region of Chile in 1987. The mean age of the children was 6.5 (SD 0.4) years ranging from 5 years 6 months to 9 years 1 month and they belonged to public (state), private-subsidised and private non-subsidised schools from both urban and rural areas. The sampling system was designed to yield a sample including approximately $1.0 \%$ of this population. The representative and proportional sample consisted of 813 school-age children randomly selected and stratified according to a multi-stage sampling system by geographic area, county, school grade, sex and type of school. For each stratum, sample size was proportional to its representation in the school-age population and was calculated with $95 \%$ reliability $(z=1.96), 3.4 \%$ of sample error, considering $p=0.5$ (males) and $q=0.5$ (females) ${ }^{(48,49)}$. This sample is representative of $38.0 \%$ of the wider Chilean school-age population $^{(49)}$. Of the original sample, $77.7 \%$ (632 schoolage children) was located in 1998 at a time when they were graduating from high school (mean age 18.0 (SD 0.7) years). The educational situation of the school-age children detected in 1998 who had been members of the original sample of school-age children enrolled in elementary first grade in 1987 was as follows: $43.2 \%$ of school-age children graduated from high school, $25.5 \%$ experienced school delay, $9 \%$ dropped out from the educational system and $22.3 \%$ could not be located ${ }^{(1,7)}$. Of the school-age children graduating from high school (351 children, $55.5 \%$ of the located sample) who were ready to take the AAT for university admission in 1998, only 260 children (74\% of the students who graduated) took the AAT in that year; the present study describes the situation of these children.

\section{Design}

This longitudinal, prospective and observational study comprises two cross-sectional stages. The first, as mentioned before, related to the survey of 1987 , was carried out in thirteen schools that belonged to eight counties from the Metropolitan Region of Chile in which 813 elementary school-age children were examined for nutritional, intellectual, socioeconomic, socio-cultural, demographic and family characteristics, mass media exposure and educational assessments. The second stage was their follow- up in 1998, at the end of the fourth year of high school, when they took the AAT for university admission. School-age children from the survey of 1987 were located in their original educational establishments, in their homes and in the Chilean universities registering their educational situation in 1998 and their scores in the AAT were recorded $^{(50)}$. The present study was approved by the Committee on Ethics in Studies in Humans of the Institute of Nutrition and Food Technology (INTA), University of Chile. The subjects' consent was obtained according to the norms for Human Experimentation, Code of Ethics of the World Medical Association (Declaration of Helsinki) ${ }^{(51)}$.

\section{Measures}

Academic aptitude test. AAT scores of 1998, both verbal and mathematics components, were registered. The AAT has a maximum score of 900 for each part (verbal test with ninety items and mathematics test with sixty items $)^{(50)}$. The AAT score represents the mean between verbal AAT and mathematics AAT. AAT scores were analysed dividing the sample into quartiles (Q) and this sample division characterised each group as significantly different from the others (Table 1). In fact, Q1 grouped students who failed in the AAT, since scores below 450 barred students from applying to higher education; Q4 includes those students who obtained the highest scores in the AAT. This division allowed us to compare 
Table 1. Description of the sample by academic aptitude test (AAT) score in 1998 divided into quartiles (Q) of school-age children enrolled in elementary first grade in 1987 graduating from high school in 1998*

(Mean values and standard deviations)

\begin{tabular}{|c|c|c|c|c|c|c|c|c|c|c|}
\hline & \multicolumn{8}{|c|}{ AAT score in 1998 (quartiles) } & \multirow[b]{3}{*}{$F$} & \multirow[b]{3}{*}{$P$} \\
\hline & \multicolumn{2}{|c|}{ Q1 (n 65) } & \multicolumn{2}{|c|}{ Q2 (n 65) } & \multicolumn{2}{|c|}{ Q3 (n 65) } & \multicolumn{2}{|c|}{ Q4 (n 65) } & & \\
\hline & Mean & SD & Mean & SD & Mean & SD & Mean & SD & & \\
\hline AAT score & $386.9^{a}$ & $25 \cdot 0$ & $477.9^{b}$ & 29.8 & $592.6^{\mathrm{C}}$ & 29.2 & $693.0^{\mathrm{d}}$ & 34.8 & 1293.1 & $<0.0001$ \\
\hline Verbal AAT score & $396 \cdot 9^{\mathrm{a}}$ & $42 \cdot 3$ & $492 \cdot 4^{\mathrm{b}}$ & $47 \cdot 7$ & $591 \cdot 6^{\mathrm{C}}$ & $52 \cdot 0$ & $671 \cdot 7^{\mathrm{d}}$ & $52 \cdot 8$ & 387.7 & $<0.0001$ \\
\hline Mathematics AAT score & $376 \cdot 8^{\mathrm{a}}$ & $33 \cdot 1$ & $463.4^{\mathrm{b}}$ & $56 \cdot 7$ & $593 \cdot 6^{\mathrm{C}}$ & $51 \cdot 6$ & $714 \cdot 3^{\mathrm{d}}$ & 53.7 & 577.5 & $<0.0001$ \\
\hline
\end{tabular}

$F$, variance.

a,b,c,d Mean values within a row with unlike superscript letters were significantly different $(P<0.05$; Scheffé's test).

* The mean AAT score in 1998 was 537.59 (SD 119.60). The AAT score is given as the mean of the verbal AAT and the mathematics AAT scores.

students who obtained the lowest scores in the AAT with their peers who obtained better outcomes.

Nutritional status assessment. Nutritional status was assessed by registering weight, height, HC, arm circumference and triceps skinfold, measured by the principal author in 1987 according to standardised procedures ${ }^{(52)}$. Nutritional status was expressed as weight-for-age $z$-score $(\mathrm{Z}-\mathrm{W})$, height-for-age $z$-score $(\mathrm{Z}-\mathrm{H})$ and weight-for-height $z$-score $(\mathrm{Z}-\mathrm{W} / \mathrm{H})^{(53)}$. According to $\mathrm{Z}-\mathrm{W}$, children were classified as undernourished $(\mathrm{Z}-\mathrm{W}<-1 \mathrm{SD})$, well-nourished $(\mathrm{Z}-\mathrm{W}$ between $-1 \mathrm{SD}$ to $+1 \mathrm{SD}$ ), overweight ( $\mathrm{Z}-\mathrm{W}$ between $>+1 \mathrm{SD}$ and $+2 \mathrm{SD}$ ) and obese (Z-W $>+2 \mathrm{SD})$; when $\mathrm{Z}-\mathrm{H}$ was used as parameter, children were classified as growth failure $(\mathrm{Z}-\mathrm{H}<-1 \mathrm{SD})$, normal height ( $\mathrm{Z}-\mathrm{H}$ between $-1 \mathrm{SD}$ and $+1 \mathrm{SD})$ and tall $(\mathrm{Z}-\mathrm{H}$ $>+1 \mathrm{SD})$. HC was compared with the tables of Ivanovic et al., and was expressed as a $z$-score $(\mathrm{Z}-\mathrm{HC})^{(54)}$. HC absolute values expressed in centimetres were adjusted for sex and body size (weight and height) through analysis of covariance ${ }^{(48)}$. In this respect, mean $\pm 2 \mathrm{SD}$ was considered 'normal $\mathrm{HC}$ ', $<-2 \mathrm{SD}$ microcephaly and $>+2$ SD macrocephaly ${ }^{(54-57)}$. Percentages of adequacy to the median for arm circumference-for-age, triceps skinfold-for-age, arm muscle area-for-age and arm fat area-for-age were calculated using data from Frisancho ${ }^{(58)}$. Birth weight was used as an index of prenatal nutrition, while $\mathrm{Z}-\mathrm{W}, \mathrm{Z}-\mathrm{H}$ and Z-HC served as indicators of postnatal nutrition and $\mathrm{Z}-\mathrm{W} / \mathrm{H}$ was used as an index of current nutritional status. Other indicators of prenatal nutrition such as height and $\mathrm{HC}$ at birth not always can be obtained from the Registry Office or from mothers. Nutritional diseases, especially undernutrition $(\mathrm{Z}-\mathrm{W}<2 \mathrm{SD})$ at an early age, were registered. No other nutritional diseases were informed by the mothers.

Intellectual ability. Intellectual ability (IA) in 1987 was assessed with Raven's Progressive Matrices Test in book form, with a special scale for children aged 4 to 11 years ${ }^{(59,60)}$. The test was administered individually by a team of trained educational psychologists and the scores were plotted according to age in a percentile (p) scale: grade I, superior IA (score $\geq$ p95); grade II, above average ( score $\geq$ p 75 and $<$ p95); grade III, average (score $>$ p25 and $<$ p75); grade IV, below average (score $>$ p5 and $\leq$ p25); grade $\mathrm{V}$, intellectually defective (score $\leq$ p5). There was no difference between the percentile scales of the sample and those obtained by Raven ${ }^{(14,59,60)}$.

Scholastic achievement test. The scholastic achievement test (SA) in 1987 was determined through Spanish language (LA) and mathematics (MA) tests (verbal and non-verbal).
Content validity was based on the fact that the test was especially designed by experts in these disciplines that are obligatory, taking into consideration the objectives pursued by the curricular programmes of the Ministry of Education $^{(61)}$. The number of items was similar for LA (sixteen) and MA (sixteen). A pilot test was carried out in fifty-five school-age children, during which its reliability was determined applying the Spearman-Brown correlation, comparing paired and unpaired items scoring 0.92 and 0.97 for LA and MA, respectively ${ }^{(48)}$. Item-test consistency for each item was measured by the Pearson correlation scoring values above 0.35 in all of them ${ }^{(48)}$. Results were expressed as percentage of achievement in overall results (SA) $(\mathrm{LA}+\mathrm{MA})$ as well as LA and MA.

Socio-economic stratum, socio-cultural, family and mass media exposure variables. SES in 1987 was measured using Graffar's modified scale which includes schooling and occupation of the head of household and characteristics of housing (building materials, ownership, water supply and ownership of durable goods), which has been validated for the Chilean urban and rural population ${ }^{(62)}$. This scale classifies the population sample into six socio-economic strata: 1, high; 2, medium-high; 3, medium; 4, medium-low; 5, low; 6, extreme poverty. In the present study, SES was grouped into three levels: high $(1+2)$, medium (3) and low $(4+5+6)$. Family characteristics such as the number of members and siblings, place among siblings, crowding, and history of family alcoholism and recreation were also registered. Mass media exposure in 1987 was assessed by applying a questionnaire based on open and closed questions that was previously tested ${ }^{(63)}$. The purpose was to know the preferences and magnitude of the exposure to radio, cinema, television, newspapers, magazines and books other than school books.

\section{Statistical analysis}

Data were processed using the SAS package (SAS Institute, Inc., Cary, NC, USA) ${ }^{(48,64)}$. Statistical analysis included variance tests (PROC ANOVA), Scheffé's test for the comparison of means, correlation (PROC CORR) and multiple regression (general linear models procedure, PROC GLM error type III). To determine significant differences between the categorical variables, $\chi^{2}$ and Fisher's tests (PROC FREQ) were used. 


\section{Results}

Of the 632 school-age children enrolled in the first grade of elementary school in 1987 and located, 351 graduated from high school in 1998 but only 260 children (74\% of the students who graduated) took the AAT. As regards the ninetyone children ( $26 \%$ of the graduated students) who did not take the AAT, $53 \%$ had not interest in taking the test, $20 \%$ of them would be working in the next year, $10 \%$ became pregnant, $10 \%$ had economic problems that would prevent them from paying the registration fee to take the AAT and $7 \%$ had a low SA. Even more, 18.1 and $50 \%$ of children who did not take the AAT belonged to high and low SES, respectively, compared with their graduated peers who took the AAT (35.6 and $19.2 \%$ respectively) ( $\chi_{0}^{2}$ (df 2) $40.291>\chi_{\mathrm{t}}^{2}$ (df 2) 13.815; $P<0.001$ ). This means that those children who did not take the AAT had parents whose schooling and occupational levels $(P<0.001)$, quality of housing $(P<0.001)$ and sewerage $(P<0.001)$ were significantly lower compared than those children who took the test. Most of the children belonging to this latter group lived in urban area $(93.5 \%)$ compared with those who did not take the AAT $(85 \%)\left(\chi_{\mathrm{o}}^{2}\right.$ (df 1) $\left.7.453>\chi_{\mathrm{t}}^{2}(\mathrm{df} 1) 6.635 ; P<0 \cdot 01\right)$. The type of school attended was different when comparing these school-age children who took and those who did not take the AAT: 34.6 and $32.3 \%$ attended public (state) schools, 31.9 and $56.4 \%$ private subsidised schools and 33.5 and $11.3 \%$ private non-subsidised schools, respectively $\left(\chi_{0}^{2}\right.$ (df 2) 29.922 > $\chi_{\mathrm{t}}^{2}$ (df 2) 13.815; $P<0.001$ ). Undernutrition at an early age was significantly more prevalent in school-age children who did not take the AAT (13\%) compared with their peers who took the AAT $(3.3 \%)\left(\chi_{0}^{2}\right.$ $($ df 1$)=9.458>\chi_{\mathrm{t}}^{2}($ df 1) $6.635 ; P<0.01)$.

The nutritional status of the 1987 sample, at the onset of elementary school, in relation to their AAT scores in 1998 is expressed in Table 2. Q1 school-age children had a postnatal nutritional background in 1987 significantly more deteriorated than their peers from Q4, since they had significantly lower values for Z-W $(P<0 \cdot 01)$, Z-H $(P<0 \cdot 001)$ and $\mathrm{Z}$-HC $(P<0.001)$ without significant differences for prenatal, current nutritional status and arm parameters. As stated previously, only $3.3 \%$ of school-age children who took the AAT had been undernourished at an early age; however, no significant differences were observed in the AAT scores (Fisher $P=0 \cdot 682$ ).

Figure 1 shows Z-W at the onset of elementary school in 1987 classified according to AAT 1998 scores expressed in quartiles. Although the prevalence of undernutrition was 13.1 and $4.6 \%$, normal nutritional status 68.9 and $56.9 \%$, overweight 11.5 and $29.2 \%$ and obesity 6.6 and $9.2 \%$ in Q1 and $\mathrm{Q} 4$, respectively, differences were not significant. Z-H at the onset of elementary school in 1987 classified by AAT 1998 scores and expressed in quartiles is shown in Fig. 2. Although height was normal in most of the children in 1987 $(75.4 \%)$, severe growth failure decreased from 3.3 to $0 \%$ from Q1 to Q4, and moderate growth failure from 27.9 to $9.2 \%$, respectively; on the contrary, students considered tall increased from $4.9 \%$ in Q1 to $15.4 \%$ in Q4 $(P<0.05)$. Figure 3 illustrates nutritional status expressed as Z-HC for school-age children enrolled in elementary first grade in 1987 in relation to their AAT scores in 1998 divided in quartiles; 41.9 and $21.6 \%$ of Q1 and Q4 school-age children had $\mathrm{Z}$-HC values in 1987 below the mean. In this respect, $4 \cdot 8$ and $0 \%$ of children from Q1 and Q4 had Z-HC values in $1987<-2$ SD, respectively. Students with Z-HC values in $1987>2$ SD represented 1.6 and $12.3 \%$ of Q1 and Q4. School-age children with Z-HC values in $1987>2$ SD increased approximately eight times from the lowest (Q1) to the highest (Q4) AAT scores $(P<0 \cdot 02)$. As defined by Z-W/H values in $1987,1.2 \%$ of school-age children were undernourished, $66.4 \%$ well-nourished, $23.8 \%$ were overweight and $8.6 \%$ were obese, without significant differences by AAT score in 1998.

Table 2. Nutritional status of Chilean school-age children at the onset of elementary school in 1987 by academic aptitude test (AAT) score in 1998 expressed as quartiles $(\mathrm{Q})$

(Mean values and standard deviations)

\begin{tabular}{|c|c|c|c|c|c|c|c|c|c|c|}
\hline \multirow[b]{3}{*}{ Nutritional status in 1987} & \multicolumn{8}{|c|}{ AAT score in 1998 (quartiles) } & \multirow[b]{3}{*}{$F$} & \multirow[b]{3}{*}{$P$} \\
\hline & \multicolumn{2}{|c|}{ Q1 (n 65) } & \multicolumn{2}{|c|}{ Q2 (n 65) } & \multicolumn{2}{|c|}{ Q3 (n 65) } & \multicolumn{2}{|c|}{ Q4 (n 65) } & & \\
\hline & Mean & SD & Mean & SD & Mean & SD & Mean & SD & & \\
\hline \multicolumn{11}{|c|}{ Prenatal nutritional background } \\
\hline Birth weight $(\mathrm{g})$ & 3199.9 & $779 \cdot 3$ & 3213.2 & 479.7 & 3404.5 & $573 \cdot 0$ & 3296.02 & $520 \cdot 3$ & 1.08 & NS \\
\hline \multicolumn{11}{|c|}{ Postnatal nutritional background } \\
\hline Z-W & $0 \cdot 15^{\mathrm{a}}$ & $1 \cdot 12$ & $0.29^{a, b}$ & 0.99 & $0.60^{a, c}$ & $1 \cdot 13$ & $0.74^{\mathrm{b}, \mathrm{c}}$ & 0.99 & $4 \cdot 10$ & $<0.01$ \\
\hline $\mathrm{Z}-\mathrm{H}$ & $-0.49^{\mathrm{a}}$ & 0.92 & $0 \cdot 15^{a, b}$ & 1.02 & $0.01^{\mathrm{b}}$ & 0.97 & $0 \cdot 18^{\mathrm{b}}$ & 0.84 & 5.77 & $<0.001$ \\
\hline $\mathrm{Z}-\mathrm{HC}$ & $0 \cdot 24^{\mathrm{a}}$ & $1 \cdot 11$ & $0.38^{a, b}$ & $1 \cdot 30$ & $0.67^{b}$ & $1 \cdot 12$ & $0 \cdot 87^{b}$ & 0.96 & 5.98 & $<0.001$ \\
\hline \multicolumn{11}{|l|}{ Current nutritional status } \\
\hline Z-W/H & 0.65 & 0.96 & 0.50 & 0.84 & 0.76 & $1 \cdot 14$ & 0.82 & 1.05 & 1.29 & NS \\
\hline \multicolumn{11}{|l|}{ Brachial anthropometry } \\
\hline$\% A C / A$ & $102 \cdot 1$ & $10 \cdot 6$ & $102 \cdot 4$ & $8 \cdot 6$ & $105 \cdot 0$ & $13 \cdot 6$ & $105 \cdot 4$ & $10 \cdot 4$ & 1.62 & NS \\
\hline$\%$ TS/A & 93.8 & $34 \cdot 2$ & $87 \cdot 8$ & $37 \cdot 1$ & $92 \cdot 1$ & 38.9 & 90.5 & $39 \cdot 2$ & 0.30 & NS \\
\hline$\%$ AMA $/ A$ & 108.5 & $18 \cdot 8$ & 111.4 & $15 \cdot 0$ & 117.4 & 34.5 & $118 \cdot 1$ & $19 \cdot 2$ & 2.56 & NS \\
\hline$\%$ AFA $/ A$ & $97 \cdot 7$ & $42 \cdot 9$ & $91 \cdot 8$ & $43 \cdot 2$ & $99 \cdot 2$ & $49 \cdot 4$ & $97 \cdot 7$ & $49 \cdot 0$ & 0.32 & NS \\
\hline
\end{tabular}

F, variance; Z-W, weight-for-age $z$-score; Z-H, height-for-age $z$-score; Z-HC, head circumference-for-age $z$-score; Z-W/H, weight-for-height $z$-score; AC/A, arm circumferencefor-age; TS/A, triceps skinfold-for-age; AMA/A, arm muscle area-for-age; AFA/A, arm fat area-for-age.

a,b,c Mean values within a row with unlike superscript letters were significantly different $(P<0.05$; Scheffé's test). 


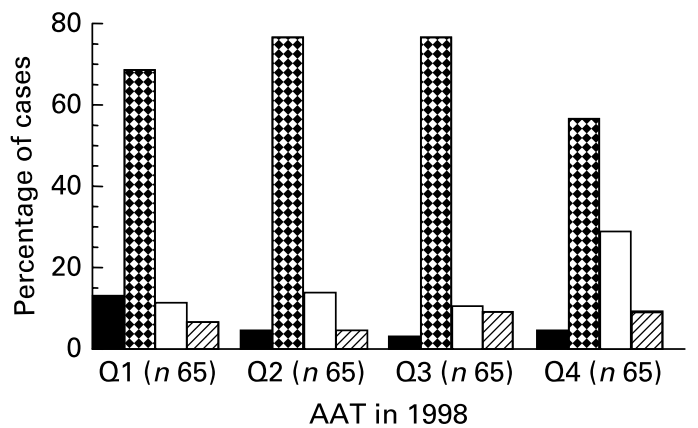

Fig. 1. Nutritional status expressed as weight-for-age $z$-score $(Z-W)$ of Chilean school-age children at the onset of elementary school in 1987 by aca-

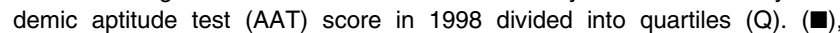
Undernourished, Z-W $<-1 \mathrm{SD}$; well-nourished, Z-W between $-1 \mathrm{SD}$ and

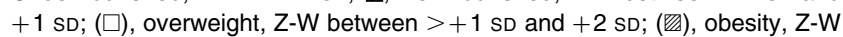
$>+2$ SD. The $\chi^{2}$ test was calculated joining the categories of Q1 + Q2 and $\mathrm{Q} 3+\mathrm{Q} 4\left(\chi_{\mathrm{o}}^{2}\right.$ (df 3) $6.025<\chi_{\mathrm{t}}^{2}$ (df 3) 7.815; $P<0.05$ ).

Table 3 shows the intellectual, demographic and educational variables at the onset of elementary school in 1987 by AAT scores in 1998 divided into quartiles. IA in 1987 was positively and significantly associated with AAT scores in 1998. The highest values for AAT scores in 1998 were obtained by urban dwellers, males and by those attending private non-subsidised schools. At the beginning of elementary school Q1 children already presented SA levels significantly lower compared with the other groups in both LA and MA. The percentage of attendance in $1987 \mathrm{did}$ not vary by AAT scores in 1998. Age in 1987 (mean 6.5 (SD 0.4 ) years) did not differ significantly by AAT scores in 1998.

Most of the Q4 school-age children belonged to high or medium SES, had head of household and mother with higher schooling and occupational levels, with better characteristics of the quality of housing, higher proportion of ownership and better sanitation, especially sewerage (Table 4). As stated previously, mean maternal schooling and schooling of the head of the household in 1987 were significantly higher in school-age children from Q4 compared with their peers from Q1 (Table 5). An inverse relationship was found between the AAT scores in 1998 and the number of family members $(r-0.050$; NS), number of siblings $(r-0.096 ; \mathrm{NS})$ and place among them $(r-0.089$; NS) and crowding $(r-0 \cdot 181$; $P<0.01$ ) (Table 5). Family alcoholism was significantly higher in school-age children from Q1 compared with Q4 $(r-0.228 ; P<0.001)$. In fact, $31 \%$ of school-age children from Q1 had an alcoholic parent (mainly the father) compared with those from Q4 (9.4\%). The father was the head of household in $91.9 \%$ of school-age children, the mother in $5.4 \%$ and another individual in $2.7 \%$, without significant differences by AAT scores in 1998.

Non-written mass media exposure in 1987 by AAT scores in 1998 expressed as quartiles are shown in Table 6. Only television watching registered a slight but significant difference in relation to AAT scores, since school-age children from Q1 had significantly higher television exposure compared with those from Q4. Written mass media exposure in 1987, newspapers, magazines and books, did not show significant differences related to AAT scores in 1998.

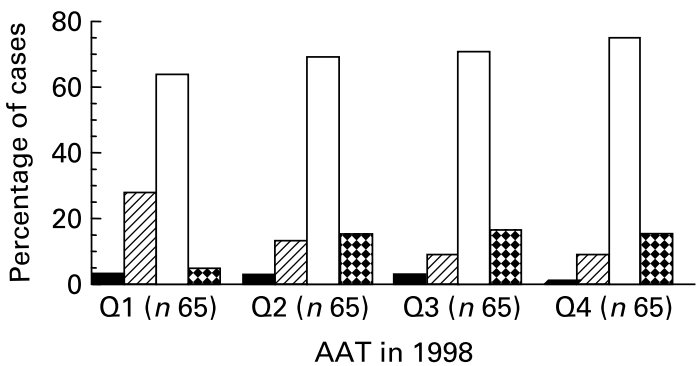

Fig. 2. Nutritional status expressed as height-for-age $z$-score $(Z-H)$ of Chilean school-age children at the onset of elementary school in 1987 by academic aptitude test (AAT) score in 1998 divided into quartiles (Q). (ם), Severe growth failure, Z-H $<-2 \mathrm{SD}$; (四), moderate growth failure, Z-H between $<-1$ SD and $-2 \mathrm{SD}$; $(\square)$, normal height, Z-H between -1 SD and $+1 \mathrm{SD}$; (国), tall, $\mathrm{Z}-\mathrm{H}>+1 \mathrm{SD}$. The $\chi^{2}$ test was calculated joining the categories of severe and moderate growth failure $\left(\chi_{\mathrm{o}}^{2}\right.$ (df 6) $15.000>\chi_{\mathrm{t}}^{2}$ (df 6) 12.592; $P<0.05)$.

Table 7 shows the Pearson correlation coefficients between AAT scores in 1998 and the most relevant parameters. All of them were significantly interrelated and were included in the multiple regression analysis. As a result, the multiple regression analysis between AAT scores in 1998 as a continuous variable (dependent variable) and the most relevant parameters entered in the statistical regression model (independent variables) (Table 8) confirms that SA in 1987 $\left(r^{2} 0.220\right)$, maternal schooling in $1987\left(r^{2} 0.118\right)$, IA in $1987\left(r^{2}\right.$ 0.047) and Z-HC in $1987\left(r^{2}\right.$ 0.017) were the independent variables with the greatest explanatory power for variance in AAT scores in $1998\left(r^{2}\right.$ 0.402).

\section{Discussion}

The results of the present study reveal that $40 \cdot 2 \%$ of the variance in AAT achievement, the baccalaureate examination for university admission in Chile, could be explained by some variables at the onset of elementary school, such as SA, maternal schooling, IA and Z-HC. However, although most variation in the variance in AAT achievement is not predictable from the first-grade background characteristics, it is noticeable that these accounted for the $40 \%$ of the variance in the AAT. AAT scores below 450 impeded students from

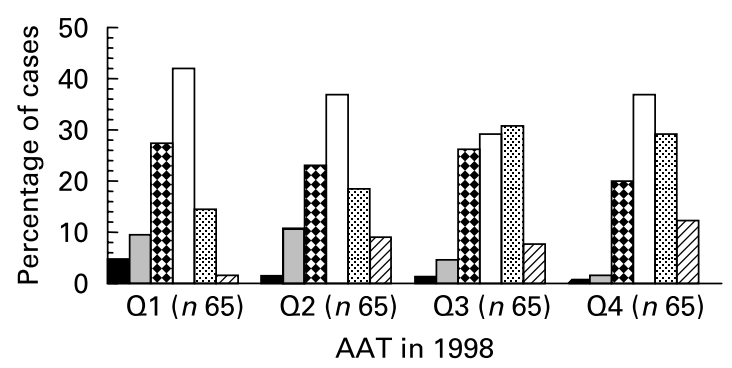

Fig. 3. Nutritional status expressed as head circumference-for-age z-score $(\mathrm{Z}-\mathrm{HC})$ of Chilean school-age children enrolled in elementary first grade in 1987 by academic aptitude test (AAT) score in 1998 divided into

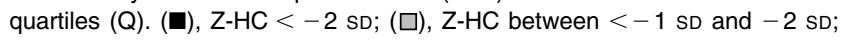
(国), Z-HC between < mean and $-1 \mathrm{SD} ;(\square)$, Z-HC between mean and +1 SD; (図), Z-HC between $>+1$ SD to +2 SD; (四), Z-HC $>+2$ SD. The $\chi^{2}$ test was calculated joining the categories of Q1 + Q2 and Q3 + Q4 ( $\chi_{\circ}^{2}(\mathrm{df} 5)$ $\left.14.323>\chi_{\mathrm{t}}^{2}(\mathrm{df} 5) 13.388 ; P<0.02\right)$. 
Table 3. Intellectual, demographic and educational variables of Chilean school-age children at the onset of elementary school in 1987 by academic aptitude test (AAT) score in 1998 expressed as quartiles (Q)

\begin{tabular}{|c|c|c|c|c|c|}
\hline & \multicolumn{4}{|c|}{ AAT in 1998 (quartiles) } & \multirow[b]{2}{*}{ Total sample $(n 260)$} \\
\hline & Q1 (n 65) & Q2 (n 65) & Q3 $(n 65)$ & Q4 (n 65) & \\
\hline \multicolumn{6}{|c|}{ IA in 1987 (Raven's test grades) (\%)* } \\
\hline Grade I & 0.0 & $7 \cdot 9$ & $10 \cdot 9$ & $20 \cdot 3$ & $9 \cdot 8$ \\
\hline Grade II & $12 \cdot 3$ & $28 \cdot 6$ & 34.4 & 39.1 & 28.5 \\
\hline Grade III & $46 \cdot 2$ & $42 \cdot 8$ & $42 \cdot 2$ & $31 \cdot 2$ & $40 \cdot 6$ \\
\hline Grade IV & $29 \cdot 2$ & $14 \cdot 3$ & $10 \cdot 9$ & 4.7 & $14 \cdot 8$ \\
\hline Grade V & $12 \cdot 3$ & $6 \cdot 4$ & 1.6 & 4.7 & $6 \cdot 3$ \\
\hline Total & $100 \cdot 0$ & $100 \cdot 0$ & $100 \cdot 0$ & $100 \cdot 0$ & $100 \cdot 0$ \\
\hline \multicolumn{6}{|c|}{ Demographic variables in 1987} \\
\hline \multicolumn{6}{|l|}{$\operatorname{Sex}(\%) \dagger$} \\
\hline Male & 38.5 & $43 \cdot 1$ & $44 \cdot 6$ & $66 \cdot 2$ & $48 \cdot 1$ \\
\hline Female & 61.5 & $56 \cdot 9$ & $55 \cdot 4$ & 33.8 & 51.9 \\
\hline Total & $100 \cdot 0$ & $100 \cdot 0$ & $100 \cdot 0$ & $100 \cdot 0$ & $100 \cdot 0$ \\
\hline \multicolumn{6}{|l|}{ Geographic area $(\%) \ddagger$} \\
\hline Urban & $83 \cdot 1$ & $92 \cdot 3$ & 98.5 & $100 \cdot 00$ & 93.5 \\
\hline Rural & $16 \cdot 9$ & 7.4 & 1.5 & 0.00 & 6.5 \\
\hline Total & $100 \cdot 0$ & $100 \cdot 0$ & $100 \cdot 0$ & $100 \cdot 0$ & $100 \cdot 0$ \\
\hline \multicolumn{6}{|l|}{ Educational variables } \\
\hline \multicolumn{6}{|l|}{ Type of school in $1987(\%) \S$} \\
\hline Public (state) & 44.6 & 41.5 & $27 \cdot 7$ & $24 \cdot 6$ & 34.6 \\
\hline Private subsidised & 44.6 & $36 \cdot 9$ & $30 \cdot 8$ & $15 \cdot 4$ & 31.9 \\
\hline Private non-subsidised & $10 \cdot 8$ & $21 \cdot 6$ & 41.5 & $60 \cdot 0$ & 33.5 \\
\hline Total & $100 \cdot 0$ & $100 \cdot 0$ & $100 \cdot 0$ & $100 \cdot 0$ & $100 \cdot 0$ \\
\hline \multicolumn{6}{|c|}{ SA in 1987 (\% correct responses) } \\
\hline \multicolumn{6}{|l|}{ SA overall results } \\
\hline Mean & $57 \cdot 6^{\mathrm{a}}$ & $71.5^{\mathrm{b}}$ & $73 \cdot 9^{\mathrm{b}, \mathrm{c}}$ & $80 \cdot 3^{\mathrm{c}}$ & \\
\hline SD & $18 \cdot 8$ & $12 \cdot 3$ & $16 \cdot 8$ & $13 \cdot 3$ & \\
\hline$F$ & 24.44 & & & & \\
\hline$P$ & $<0.0001$ & & & & \\
\hline \multicolumn{6}{|l|}{ LA } \\
\hline Mean & $43 \cdot 4^{\mathrm{a}}$ & $62 \cdot 1^{\mathrm{b}}$ & $67 \cdot 7^{\mathrm{b}, \mathrm{c}}$ & $76 \cdot 3^{\mathrm{c}}$ & \\
\hline SD & $23 \cdot 8$ & $19 \cdot 5$ & $21 \cdot 6$ & $20 \cdot 1$ & \\
\hline$F$ & $27 \cdot 62$ & & & & \\
\hline$P$ & $<0.0001$ & & & & \\
\hline \multicolumn{6}{|l|}{ MA } \\
\hline Mean & $71.9^{\mathrm{a}}$ & $80 \cdot 8^{\mathrm{b}}$ & $80.0^{\mathrm{b}}$ & $84 \cdot 2^{\mathrm{b}}$ & \\
\hline SD & 1.98 & $10 \cdot 6$ & $17 \cdot 1$ & $13 \cdot 8$ & \\
\hline$F$ & $7 \cdot 14$ & & & & \\
\hline$P$ & $<0.0001$ & & & & \\
\hline
\end{tabular}

IA, intellectual ability; SA, scholastic achievement; F, variance; LA, Spanish language achievement; MA, mathematics achievement.

a,b,c Mean values within a row with unlike superscript letters were significantly different $(P<0.05$; Scheffé's test).

${ }^{*}$ IA grades: grade I, superior; grade II, above average; grade III, average; grade IV, below average; grade V, intellectually defective. $\chi_{0}^{2}$ (df 12 ) $45.688>\chi_{\mathrm{t}}^{2}$ (df 12 ) 32.909 $(P<0.001)$

$\dagger \chi_{0}^{2}\left(\right.$ df 3) $11.879>\chi_{\mathrm{t}}^{2}(\mathrm{df} 3) 11.341(P<0.01)$

¥ Fisher $P=0.0018$. Fisher's test was calculated joining the categories $(\mathrm{Q} 1+\mathrm{Q} 2)$ and $(\mathrm{Q} 3+\mathrm{Q} 4)$.

$\S \chi_{\circ}^{2}$ (df 6) $42.654>\chi_{\mathrm{t}}^{2}($ df 6) $22.457(P<0.001)$.

applying to higher education and these scores were obtained mainly by those children from Q1 and Q2 who exhibited a more deprived nutritional, intellectual, socio-economic, socio-cultural, family and educational situation at the onset of elementary school.

SA in the first grade of elementary school in 1987 was the most important predictor of a successful achievement in the AAT in 199812 years later, since it attained first place in the statistical regression model. Previous results showed a high degree of correlation between AAT score and SA both for males and females ${ }^{(8)}$. On the other hand, SA positively and significantly correlates with genetic and environmental factors, such as child IQ, maternal and parental IQ, birth weight, birth height, undernutrition in the first year of life, Z-HC and brain volume; however, the child's IQ is the most important variable that explains $\mathrm{SA}$ and AAT variances $^{(5,6,8-10,47)}$. It is well known that SA is significantly higher in students attending private non-subsidised schools, originating from high SES and urban areas. This is logical since private non-subsidised schools offer the best quality of education, have adequate infrastructure, they hire teachers with a better academic background who apply methodologies based on best practices and, in addition, they enrol school-age children with superior IA from the high SES, whose parents have higher levels of income and schooling and live in better housing conditions; this probably creates environmental conditions more adequate for the learning process ${ }^{(5,14,47,65)}$. In the present study, the inverse relationships between the number of family members and siblings, the place among siblings and crowding, and the AAT score in 1998 is similar to the findings of other investigators; this may be explained by the fact that more children in a household imply a dilution of resources as well as of the time available for appropriate care or stimulation $^{(66)}$. 
Table 4. Socio-economic variables of Chilean school-age children at the onset of elementary school in 1987 by academic aptitude test (AAT) score in 1998 expressed as quartiles $(\mathrm{Q})(\%$ of cases $)$

\begin{tabular}{|c|c|c|c|c|c|c|}
\hline \multirow[b]{2}{*}{$\begin{array}{l}\text { Socio-economic } \\
\text { variables in } 1987\end{array}$} & \multicolumn{5}{|c|}{ AAT in 1998 (quartiles) } & \multirow[b]{2}{*}{$\chi^{2}$ or Fisher } \\
\hline & $\mathrm{Q}_{1}(n 65)$ & $\mathrm{Q}_{2}(n 65)$ & $\mathrm{Q}_{3}(n 65)$ & $\mathrm{Q}_{4}(n 65)$ & $\begin{array}{l}\text { Total sample } \\
\quad(n \text { 260) }\end{array}$ & \\
\hline Socio-economic stratum (\%) & & & & & & $\chi_{\mathrm{o}}^{2}(\mathrm{df} 6) 62.027>\chi_{\mathrm{t}}^{2}(\mathrm{df} 6) 22.457(P<0.001)$ \\
\hline High & $12 \cdot 3$ & $24 \cdot 6$ & $44 \cdot 6$ & 61.5 & $35 \cdot 6$ & \\
\hline Medium & $43 \cdot 1$ & $60 \cdot 0$ & $43 \cdot 1$ & 33.9 & $45 \cdot 0$ & \\
\hline Low & 44.6 & $15 \cdot 4$ & $12 \cdot 3$ & 4.6 & 19.4 & \\
\hline Total & $100 \cdot 0$ & $100 \cdot 0$ & $100 \cdot 0$ & $100 \cdot 0$ & $100 \cdot 0$ & \\
\hline Head of household schooling & & & & & & $\chi_{\circ}^{2}($ df 9$) 45.838>\chi_{\mathrm{t}}^{2}($ df 9$) 27.877(P<0.001)$ \\
\hline Illiterate & 0.0 & 0.0 & 0.0 & 0.0 & 0.0 & \\
\hline Incomplete elementary school & $17 \cdot 0$ & $1 \cdot 7$ & 4.9 & 0.0 & $5 \cdot 8$ & \\
\hline Complete elementary school & $5 \cdot 0$ & $13 \cdot 3$ & $3 \cdot 3$ & $3 \cdot 2$ & $6 \cdot 2$ & $\begin{array}{l}\text { The } \chi^{2} \text { test was calculated joining the } \\
\text { categories (illiterate }+ \text { incomplete } \\
\text { elementary school + complete } \\
\text { elementary school) and (incomplete }+ \\
\text { complete university education) }\end{array}$ \\
\hline Incomplete high school & 23.7 & $13 \cdot 3$ & 4.9 & 4.8 & $11 \cdot 6$ & \\
\hline Complete high school & $37 \cdot 3$ & $46 \cdot 7$ & 34.4 & $30 \cdot 7$ & $37 \cdot 1$ & \\
\hline Incomplete university education & $5 \cdot 1$ & $1 \cdot 7$ & 4.9 & 1.6 & $3 \cdot 3$ & \\
\hline Complete university education & 11.9 & $23 \cdot 3$ & $47 \cdot 6$ & $59 \cdot 7$ & $36 \cdot 0$ & \\
\hline Total & $100 \cdot 0$ & $100 \cdot 0$ & $100 \cdot 0$ & $100 \cdot 0$ & $100 \cdot 0$ & \\
\hline Maternal schooling & & & & & & $\chi_{0}^{2}($ df 9$) 58.197>\chi_{\mathrm{t}}^{2}(\mathrm{df} 9) 27.877(P<0.001)$ \\
\hline Illiterate & 1.7 & 0.0 & 0.0 & 0.0 & 0.4 & \\
\hline Incomplete elementary school & $17 \cdot 2$ & 11.4 & $3 \cdot 3$ & $1 \cdot 7$ & 8.4 & \\
\hline Complete elementary school & $12 \cdot 1$ & $6 \cdot 6$ & $3 \cdot 3$ & $5 \cdot 0$ & $6 \cdot 7$ & \\
\hline Incomplete high school & $24 \cdot 1$ & $14 \cdot 8$ & $15 \cdot 0$ & $6 \cdot 7$ & $15 \cdot 0$ & $\begin{array}{l}\text { The } \chi^{2} \text { test was calculated joining the } \\
\text { categories (illiterate }+ \text { incomplete } \\
\text { elementary school }+ \text { complete elementary } \\
\text { school) and (incomplete }+ \text { complete } \\
\text { university education) }\end{array}$ \\
\hline Complete high school & 37.9 & 57.4 & 53.4 & $35 \cdot 0$ & $46 \cdot 0$ & \\
\hline Incomplete university education & 3.5 & 1.6 & $5 \cdot 0$ & $3 \cdot 3$ & 3.4 & \\
\hline Complete university education & 3.5 & 8.2 & $20 \cdot 0$ & $48 \cdot 3$ & $20 \cdot 1$ & \\
\hline Total & $100 \cdot 0$ & $100 \cdot 0$ & $100 \cdot 0$ & $100 \cdot 0$ & $100 \cdot 0$ & \\
\hline Occupation of head of household & & & & & & $\chi_{\circ}^{2}(\mathrm{df} 6) 52.781>\chi_{\mathrm{t}}^{2}(\mathrm{df} 6) 22.457(P<0.001)$ \\
\hline 1. Managerial positions & 0.0 & 1.5 & 0.0 & 4.6 & 1.5 & \\
\hline 2. Mid-level employee & $13 \cdot 9$ & $29 \cdot 2$ & $52 \cdot 3$ & $66 \cdot 2$ & $40 \cdot 4$ & $\begin{array}{l}\text { The } \chi^{2} \text { test was calculated joining the } \\
\text { categories }(1+2) \text { and }(4+5+6)\end{array}$ \\
\hline 3. Specialised worker & $56 \cdot 9$ & 53.9 & $32 \cdot 3$ & $24 \cdot 6$ & 41.9 & \\
\hline 4. Non-specialised worker & $29 \cdot 2$ & $12 \cdot 3$ & $13 \cdot 9$ & 4.6 & $15 \cdot 0$ & \\
\hline 5. Jobless receiving state aid & 0.0 & $3 \cdot 1$ & 0.0 & 0.0 & 0.8 & \\
\hline $\begin{array}{l}\text { 6. Jobless without state aid } \\
\text { (housekeepers) }\end{array}$ & 0.0 & 0.0 & 1.5 & 0.0 & 0.4 & \\
\hline Total & $100 \cdot 0$ & $100 \cdot 0$ & $100 \cdot 0$ & $100 \cdot 0$ & $100 \cdot 0$ & \\
\hline Maternal occupation & & & & & & $\begin{array}{l}\chi_{\mathrm{o}}^{2}(\mathrm{df} 6)=30.058>\chi_{\mathrm{t}}^{2}(\mathrm{df} 6) 22.457 \\
\quad(P<0.001)\end{array}$ \\
\hline 1. Managerial positions & 0.0 & 0.0 & 0.0 & 1.5 & 0.4 & \\
\hline 2. Mid-level employee & 1.5 & 1.5 & $10 \cdot 9$ & $21 \cdot 5$ & $8 \cdot 9$ & $\begin{array}{l}\text { The } \chi^{2} \text { test was calculated joining the } \\
\text { categories }(1+2) \text { and }(4+5+6)\end{array}$ \\
\hline 3. Specialised worker & $16 \cdot 9$ & $18 \cdot 5$ & $29 \cdot 7$ & 21.5 & $21 \cdot 6$ & \\
\hline 4. Non-specialised worker & $7 \cdot 7$ & $6 \cdot 2$ & 1.6 & 1.5 & $4 \cdot 2$ & \\
\hline 5. Jobless receiving state aid & 0.0 & 1.5 & 0.0 & 0.0 & 0.4 & \\
\hline $\begin{array}{l}\text { 6. Jobless without state aid } \\
\text { (housekeepers) }\end{array}$ & $73 \cdot 9$ & $72 \cdot 3$ & $57 \cdot 8$ & $54 \cdot 0$ & 64.5 & \\
\hline Total & $100 \cdot 0$ & $100 \cdot 0$ & $100 \cdot 0$ & $100 \cdot 0$ & $100 \cdot 0$ & \\
\hline Quality of housing & & & & & & $\begin{array}{l}\chi_{\mathrm{o}}^{2}(\mathrm{df} 12) 63.240>\chi_{\mathrm{t}}^{2}(\mathrm{df} 12) 32.909 \\
\quad(P<0.001)\end{array}$ \\
\hline Single family unit & $7 \cdot 7$ & 9.5 & 21.9 & $27 \cdot 6$ & $16 \cdot 7$ & \\
\hline Solid materials & 4.6 & $20 \cdot 6$ & $32 \cdot 8$ & $46 \cdot 2$ & $26 \cdot 1$ & \\
\hline Light materials & 55.4 & 49.2 & $32 \cdot 8$ & $23 \cdot 1$ & $40 \cdot 1$ & \\
\hline Self-built & $29 \cdot 2$ & $19 \cdot 1$ & $12 \cdot 5$ & $3 \cdot 1$ & $16 \cdot 9$ & \\
\hline Precarious housing ('mejora') & 3.1 & 1.6 & 0.0 & 0.0 & $1 \cdot 2$ & \\
\hline Total & $100 \cdot 0$ & $100 \cdot 0$ & $100 \cdot 0$ & $100 \cdot 0$ & $100 \cdot 0$ & \\
\hline Property of housing & & & & & & $\chi_{0}^{2}(\mathrm{df} 6) 22.028>\chi_{\mathrm{t}}^{2}(\mathrm{df} 6) 22.457(P<0.001)$ \\
\hline Owners & $47 \cdot 7$ & $60 \cdot 3$ & $65 \cdot 6$ & 61.5 & $58 \cdot 8$ & \\
\hline Tenants & $24 \cdot 6$ & $28 \cdot 6$ & 29.7 & 33.9 & 29.2 & \\
\hline Usufructuaries & 3.1 & 1.6 & 0.0 & 1.5 & 1.5 & $\begin{array}{l}\text { The } \chi^{2} \text { test was calculated joining the } \\
\text { categories (usufructuaries }+ \text { entourages) }\end{array}$ \\
\hline Entourages & $24 \cdot 6$ & 9.5 & 4.7 & $3 \cdot 1$ & 10.5 & \\
\hline Total & $100 \cdot 0$ & $100 \cdot 0$ & $100 \cdot 0$ & $100 \cdot 0$ & $100 \cdot 0$ & \\
\hline
\end{tabular}


Table 4. Continued

\begin{tabular}{|c|c|c|c|c|c|c|}
\hline \multirow[b]{2}{*}{$\begin{array}{l}\text { Socio-economic } \\
\quad \text { variables in } 1987\end{array}$} & \multicolumn{5}{|c|}{ AAT in 1998 (quartiles) } & \multirow[b]{2}{*}{$\chi^{2}$ or Fisher } \\
\hline & $\mathrm{Q}_{1}(n 65)$ & $\mathrm{Q}_{2}(n 65)$ & $\mathrm{Q}_{3}(n 65)$ & $\mathrm{Q}_{4}(n 65)$ & $\begin{array}{l}\text { Total sample } \\
\quad(n 260)\end{array}$ & \\
\hline Sewerage & & & & & & Fisher $P<0.0101$ \\
\hline With sewerage & $89 \cdot 2$ & $96 \cdot 8$ & $98 \cdot 4$ & $100 \cdot 0$ & $96 \cdot 1$ & $\begin{array}{l}\text { Fisher's test was calculated joining the } \\
\text { categories }(\mathrm{Q} 1+\mathrm{Q} 2) \text { and }(\mathrm{Q} 3+\mathrm{Q} 4)\end{array}$ \\
\hline Without sewerage & $10 \cdot 8$ & 3.2 & 1.6 & 0.0 & 3.9 & \\
\hline Total & $100 \cdot 0$ & $100 \cdot 0$ & $100 \cdot 0$ & $100 \cdot 0$ & $100 \cdot 0$ & \\
\hline Water supply & & & & & & Fisher $P=1.00$ \\
\hline With drinking water & $100 \cdot 0$ & $98 \cdot 4$ & $98 \cdot 4$ & $100 \cdot 0$ & $99 \cdot 2$ & $\begin{array}{l}\text { Fisher's test was calculated joining the } \\
\text { categories }(\mathrm{Q} 1+\mathrm{Q} 2) \text { and }(\mathrm{Q}+\mathrm{Q} 4)\end{array}$ \\
\hline Without drinking water & 0.0 & 1.6 & 1.6 & 0.0 & 0.8 & \\
\hline Total & $100 \cdot 0$ & $100 \cdot 0$ & $100 \cdot 0$ & $100 \cdot 0$ & $100 \cdot 0$ & \\
\hline
\end{tabular}

Maternal schooling in 1987 occupied the second place in the statistical regression model and was the most important socio-economic and socio-cultural predictor that explains AAT scores in 1998. This confirms our previous results that maternal schooling is the most relevant socio-economic and socio-cultural variable that explains $\mathrm{SA}$ and $\mathrm{IA}^{(6,8,9,13,14,65)}$. Maternal schooling is probably related with a higher maternal IQ that may favour a more intensive stimulation of the child ${ }^{(67-69)}$. On the other hand, the positive and significant impact of parental schooling, especially maternal schooling, on children's IQ has been described by several authors $^{(38,70-73)}$. The impact on SA of the quality of housing may also be related to a more intensive stimulation of the child. The same explanation may be used for other socio-economic variables such as SES, maternal and paternal occupation, head of household (father), sewerage and water supply, which were found to be positively and significantly correlated with $\mathrm{SA}$, results that are in agreement with those from other authors, although these did not contribute to explain SA variance $^{(11,12,74-76)}$. Other findings have revealed that the presence of the father in the household is associated with significant differences favouring the academic achievement

Table 5. Parental schooling and family characteristics of Chilean school-age children at the onset of elementary school in 1987 by academic aptitude test (AAT) score in 1998 expressed as quartiles (Q)

(Mean values and standard deviations)

\begin{tabular}{|c|c|c|c|c|c|c|c|c|c|c|}
\hline \multirow[b]{3}{*}{ Family variables in 1987} & \multicolumn{8}{|c|}{ AAT in 1998 (quartiles) } & \multirow[b]{3}{*}{$F$} & \multirow[b]{3}{*}{$P$} \\
\hline & \multicolumn{2}{|c|}{ Q1 (n 65) } & \multicolumn{2}{|c|}{ Q2 (n 65) } & \multicolumn{2}{|c|}{ Q3 (n 65) } & \multicolumn{2}{|c|}{ Q4 (n 65) } & & \\
\hline & Mean & SD & Mean & SD & Mean & SD & Mean & SD & & \\
\hline Head of household schooling (years) & $11 \cdot 7^{\mathrm{a}}$ & 3.0 & $12 \cdot 8^{\mathrm{a}, \mathrm{b}}$ & 2.6 & $14 \cdot 0^{\mathrm{b}, \mathrm{c}}$ & $2 \cdot 6$ & $14 \cdot 6^{c}$ & 1.9 & $16 \cdot 12$ & $<0.0001$ \\
\hline Maternal schooling (years) & $10 \cdot 9^{\mathrm{a}}$ & 2.9 & $12 \cdot 0^{b, c}$ & $2 \cdot 7$ & $13 \cdot 2^{b, c}$ & $2 \cdot 0$ & $14 \cdot 1^{\mathrm{c}}$ & $2 \cdot 2$ & $19 \cdot 30$ & $<0.0001$ \\
\hline Number of family members & $5 \cdot 6$ & 1.7 & 5.3 & 1.7 & $5 \cdot 2$ & 1.4 & $5 \cdot 3$ & 1.3 & 0.62 & NS \\
\hline Number of siblings & 1.8 & 1.4 & 1.7 & 1.1 & 1.6 & 1.1 & 1.6 & 1.0 & 0.42 & NS \\
\hline Place among siblings & $2 \cdot 1$ & 1.4 & $2 \cdot 0$ & $1 \cdot 2$ & $2 \cdot 0$ & 1.2 & $1 \cdot 8$ & $1 \cdot 2$ & 0.62 & NS \\
\hline Crowding (persons per bedroom) & $2 \cdot 1^{\mathrm{a}}$ & 0.9 & $1 \cdot 8^{\mathrm{a}, \mathrm{b}}$ & 0.7 & $1 \cdot 8^{\mathrm{a}, \mathrm{b}}$ & 0.8 & $1 \cdot 6^{\mathrm{b}}$ & 0.5 & 4.35 & $<0.01$ \\
\hline
\end{tabular}

$F$, variance.

a,b,c Mean values within a row with unlike superscript letters were significantly different $(P<0.05$; Scheffé's test).

Table 6. Non-written mass media exposure (MME) of Chilean school-age children at the onset of elementary school in 1987 by academic aptitude test (AAT) score in 1998 expressed as quartiles (Q)

(Mean values and standard deviations)

\begin{tabular}{|c|c|c|c|c|c|c|c|c|c|c|}
\hline \multirow[b]{3}{*}{ MME in 1987} & \multicolumn{8}{|c|}{ AAT in 1998 (quartiles) } & \multirow[b]{3}{*}{$F$} & \multirow[b]{3}{*}{$P$} \\
\hline & \multicolumn{2}{|c|}{ Q1 ( $n$ 65) } & \multicolumn{2}{|c|}{ Q2 (n 65) } & \multicolumn{2}{|c|}{ Q3 (n 65) } & \multicolumn{2}{|c|}{ Q4 (n 65) } & & \\
\hline & Mean & SD & Mean & SD & Mean & SD & Mean & SD & & \\
\hline Radio (min/d) & $28 \cdot 5$ & 38.6 & $28 \cdot 0$ & $24 \cdot 0$ & $29 \cdot 6$ & $46 \cdot 2$ & $22 \cdot 9$ & $28 \cdot 2$ & 0.46 & NS \\
\hline Cinema (times/month) & 0.2 & 0.8 & 0.5 & 0.9 & 0.5 & 0.9 & 0.5 & 1.1 & 1.30 & NS \\
\hline Television $(\mathrm{min} / \mathrm{d})$ & $142 \cdot 2^{\mathrm{a}}$ & 87.4 & $123 \cdot 4^{\mathrm{a}, \mathrm{b}}$ & 73.6 & $131 \cdot 7^{\mathrm{a}, \mathrm{b}}$ & 88.6 & $101 \cdot 2^{\mathrm{b}}$ & $77 \cdot 8$ & $2 \cdot 88$ & $<0.05$ \\
\hline
\end{tabular}

$F$, variance.

${ }^{a, b}$ Mean values within a row with unlike superscript letters were significantly different $(P<0 \cdot 05$; Scheffé's test). 


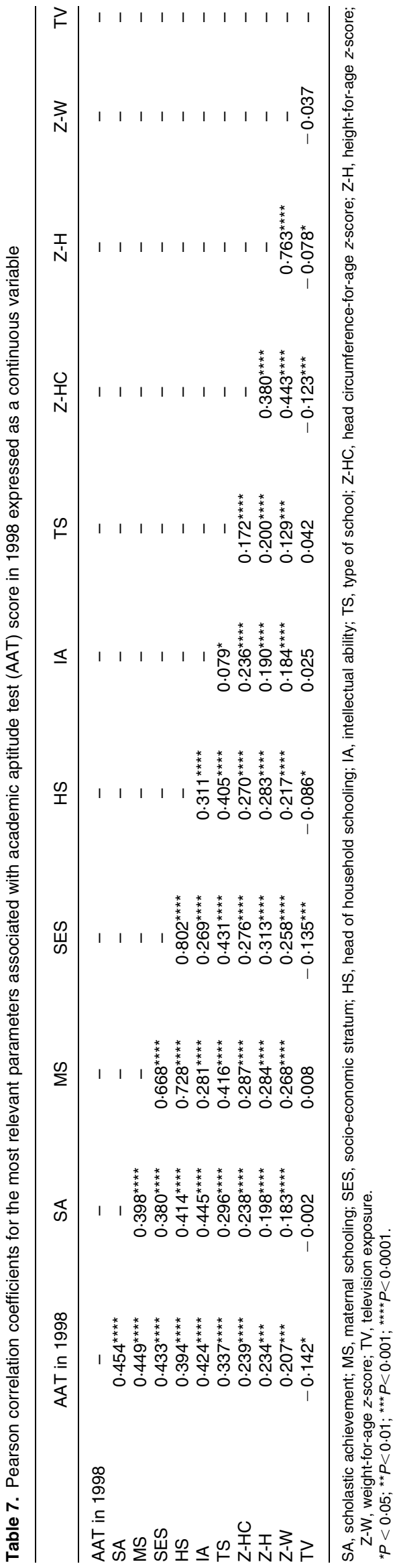

of boys and girls ${ }^{(77)}$. Socio-economic conditions are also strongly correlated with the quality of stimulation at home, so that SA probably does not depend solely on the IQ, but also on environmental factors. The positive impact of parental (especially maternal) IQ has been underlined as one of the most important environmental factors affecting children's intelligence and may be related to the quality of the stimulation provided, which in conditions of poverty is strongly limited by lower schooling levels ${ }^{(10,38,67-73,78)}$. Other findings reveal that, regardless of class or marital status, mothers have primary responsibility over school choice ${ }^{(79)}$. A recent study suggests that parents who demonstrated more warmth and engaged in more discussions concerning academic and intellectual matters with their adolescent offspring also had higher school aspirations for their adolescents, and these had the better school grades. In contrast, in adolescents who were characterised by below-average ability, parental school involvement and capability beliefs demonstrated the worst school performance ${ }^{(80)}$.

IA in 1987 appears as the third predictor of AAT achievement in 1998 and is one of the most important determinant for SA in all grades and age-groups ${ }^{(1,5,6,8-10,47,81,82)}$. Our previous findings revealed that in the sample of the present study, IA is the most important variable that explains SA at the onset of elementary school ${ }^{(47)}$; however, these results are not different from our recent studies in Chilean school-age children graduating from high school, since intelligence explains approximately $90 \%$ of SA and AAT variances in both males and females ${ }^{(8-10)}$.

$\mathrm{HC}$ in 1987 is the fourth predictor of AAT achievement in 1998. HC is an indicator of both nutritional background and brain development; children with the lowest scores in the AAT in 1998 had the lowest Z-HC values. From this, we hypothesise that children with suboptimal $\mathrm{HC}$ have some degree of alteration of their brain development associated with the lower SA, IA and AAT scores and this was confirmed by our previous studies ${ }^{(1,3-6,8-10,13,47)}$. The age-dependent HC:brain volume relationship, particularly in young children, is an accurate, rapid and inexpensive parameter of brain size and growth ${ }^{(23)}$. Results from several authors reported positive and significant correlations between SA, maternal schooling, maternal IQ, child IQ, HC and brain size $^{(1,3-6,8-10,13,21,23,27,31-39,45,46,83-85)}$. As previously stated, educational desertion relates to $\mathrm{HC}$ but not to weight or height $^{(22)}$. This could explain that only Z-HC in 1987 entered in the statistical regression model, since undernourished children in 1987 did not achieve lower AAT scores in 1998 than their well-nourished peers in 1987. Children with growth failure in 1987 achieved slight but significantly lower results than their peers with normal or above-average height in 1987; however, the statistical significance for the association between AAT score in 1998 and HC was higher. Differences in HC (or brain size) at the onset of elementary school are relevant to explain differences in AAT score 12 years later. This fact is relevant since at age 6 years when children begin their elementary school, $90 \%$ of adult $\mathrm{Z}$-HC is already completed and emphasises the importance of an adequate nutrition in the prenatal life and during the first 2 years of life ${ }^{(53)}$. The first 2 years of life represent the period of maximum brain growth and by the end of the first year of life, $70 \%$ of the adult brain weight has been 
Table 8. Multiple regression analysis (PROC GLM error type III) between academic aptitude test (AAT) score in 1998 expressed as a continuous variable (dependent variable) and the most relevant parameters (independent variables)*

\begin{tabular}{|c|c|c|c|c|c|c|c|}
\hline Step & Parameter entered & Partial $r^{2}$ & Model $r^{2}$ & Estimate & $\mathrm{T}$ for $\mathrm{HO}$ : parameter $=0$ & $P>|\mathrm{T}|$ & SE of estimate \\
\hline & Intercept & - & - & 285.7192192 & $6 \cdot 10$ & 0.0001 & $46 \cdot 80860845$ \\
\hline 1 & SA in 1987 & 0.220 & 0.220 & 1.9644293 & 4.57 & 0.0001 & 0.42975769 \\
\hline 2 & Maternal schooling & 0.118 & 0.338 & 14.4208951 & $6 \cdot 19$ & 0.0001 & 2.32853236 \\
\hline 3 & IA in 1987 & 0.047 & 0.385 & -26.5371003 & 3.98 & 0.0001 & 6.66040207 \\
\hline 4 & Z-HC in 1987 & 0.017 & 0.402 & 13.4194540 & 2.54 & 0.0118 & $5 \cdot 28757591$ \\
\hline
\end{tabular}

SA, scholastic achievement; IA, intellectual ability; Z-HC, head circumference-for-age $z$-score.

*PROC GLM general linear models procedure (SAS Institute, Inc., Cary, NC, USA). Root mean squared error (standard deviation of the dependent variable AAT $)=92.681704 ;$ model $F$ value $=38.26(P<0.0001)$.

attained $^{(22,25)}$. In a previous study comparing undernourished and well-nourished poor Chilean high-school graduates, the most relevant independent variables explaining IQ were, in decreasing order, maternal schooling, brain volume and undernutrition in the first year of life $\left(r^{2} 0.714\right)$ and IQ explained most part of SA variance $\left(r^{2} 0 \cdot 860\right)^{(9)}$. Findings from other authors revealed that late entry into secondary school was more frequent among the small-for-gestational-age than in the appropriate-for-gestational-age children after adjustments were made for maternal age and educational level, parental socio-economic status, family size, and sex. A significantly higher proportion of term, small-for-gestational-age adolescents failed to take or pass the baccalaureate examination than the appropriate-for-gestational-age adolescents. Smallfor-gestational-age participants with a smaller HC entered secondary school later more often than their small-for-gestational-age peers with a larger $\mathrm{HC}$, but the association was not significant after adjustment ${ }^{(86)}$.

School desertion has always been a permanent concern in Chile. During the decade of the 1980s, an important increase was observed in graduation from elementary and high schools and in the enrolment into university education when comparing with previous decades. In the 1990s, of those attending elementary and high schools, graduation increased to 79 and $53 \%$, respectively, and $42 \%$ enrolled into higher education. These retention rates represent approximately those found in the present study, since $55.5 \%$ of the located sample incorporated in 1987 graduated from high school in 1998, and 41\% took the AAT for university admission in 1999; however, this also means that $59 \%$ of school-age children did not take the AAT and did not enrol into higher education.

Since 1990, a Quality of Education Improvement Program (MECE) has been implemented to improve the quality of the educational process, equity and efficiency of the conditions, processes and outcomes at all levels of the educational system, focusing efforts especially on the more deprived children ${ }^{(87,88)}$. This is relevant, since in the sample that was the object of the present study SES, IA, SA and Z-HC at the onset of elementary school in 1987 were the independent variables with the greatest explanatory power for the educational status of school-age children in 1998 and significantly affected school dropout rates ${ }^{(7)}$.

Despite all efforts through public policies to improve health and education focused on the most deprived children and starting from an early age ${ }^{(87,88)}, 59 \%$ of the sample of the located schoolchildren did not take the AAT. This means that most students do not take a pathway that, through attendance to a university, will lead to improvements of their living standards and will emphasise the extremity of socio-economic disparities in Chile. AAT scores below 450 bar students from applying to higher education and these scores were obtained mainly by children from Q1, who failed the AAT. They also exhibited a more deprived global situation at the onset of elementary school and were exposed from an early age to multiple risks. In consequence, they subsequently hold low-paying jobs that result in unfavourable conditions for their own children, thus contributing to the vicious circle of poverty ${ }^{(89,90)}$. UNICEF has stated that the rates of high school desertion have been insufficiently studied, considering that more than a million and a half children between 15 and 24 years of age have not completed their high school ${ }^{(91,92)}$.

In conclusion, (i) the low proportion of high-school graduates and the low percentage of students who take the AAT are in agreement with the Chilean national school retention rates; (ii) however, a shortcoming of the present study is that $22.3 \%$ of the original sample could not be located; it is probable that some of them graduated from high school in other parts of Chile $^{(7)}$; (iii) considering the relevant impact of SA, maternal schooling, IA and Z-HC (an anthropometric indicator of nutritional background and brain development and the most sensitive physical index of undernutrition at an early age) as risk factors present at an early age that explain AAT scores 12 years later, the present results emphasise that children under the age of 3 years, and pregnant or breast-feeding mothers should be the centre of public policies of education and food and nutritional safety in order to protect their infants even before they are born ${ }^{(93)}$.

The present results reveal that some developmental variables present in children at the onset of elementary school are relevant in explaining AAT scores and these risk factors could predict achievement 12 years later. These findings do not imply determinism and to some extent may be reversible. Along the school years, the nutritional, family, educational and socio-economic conditions of the more deprived children could be improved but the educational system, mainly in developing countries, does not constitute an adequate organisation geared to provide help to these students according to their individual differences. For example, schools lack multiprofessional health teams including physicians, psychologists, nurses, or nutritionists who could support the pedagogical process. Providing opportunities remains vital throughout life for sustained socio-economic improvement in order to avoid poor children growing into poor adults ${ }^{(89)}$. Taking into account these findings, a health and educational plan for school-age children with special needs at an early age could be a successful initiative. 


\section{Acknowledgements}

The authors are very grateful to the Ministry of Education of Chile for all the facilities given to carry out this research, and to Oscar Brunser, MD, for helpful comments and suggestions.

The present study was supported in part by grants 1841167 and 1880818 from the National Fund for Scientific and Technologic Development (FONDECYT), grants S 2169-924 F and EO11-97/2 from the Research and Development Department (DID), University of Chile and grant 019/1997 from the University of Chile, Postgraduate Department.

The data for the present paper are part of two theses submitted by M. del P. N. R. and by A. L. C. in partial fulfilment of the requirements for the Master of Nutritional Sciences degree from the Institute of Nutrition and Food Technology (INTA), University of Chile and for the Master of Public Health (MPH) from the School of Public Health, Loma Linda University, respectively.

D. M. I. and R. M. I. are guarantors and participated in all the steps of the research. M. del P. N. R. and A. L. C. were responsible for the field study and conscript data. H. T. P., J. A. A., A. F. A. and T. D. T. contributed to writing and refining of the manuscript. M. S. C. U. was responsible for the intellectual assessment. Nora Díaz and Bárbara Leyton performed the statistical analysis.

The authors declare no conflict of interest.

\section{References}

1. Ivanovic D (2003) Características de los alumnos asociadas a su trayectoria escolar (Characteristics of students associated with their school career). In En 12 Años de Escolaridad Obligatoria (12 Years of Compulsory Schooling), pp. 119-126 [C Belleï and F Fiabiane, editors]. Santiago: LOM-PIIE-UNICEF.

2. Ivanovic D \& Ivanovic R (1988) Rendimiento y deserción escolar: un enfoque multicausal (Performance and dropout: a multiple approach). In En Rendimiento Escolar y Estado Nutricional (School Performance and Nutritional Status), pp. 3-6 [D Ivanovic, R Ivanovic and S Middleton, editors]. Santiago: Universidad de Chile, Institute of Nutrition and Food Technology (INTA).

3. Ivanovic DM, Leiva BP, Castro CG, et al. (2004) Brain development parameters and intelligence in Chilean high school graduates. Intelligence 32, 461-479.

4. Ivanovic DM, Leiva BP, Pérez HT, et al. (2004) Head size and intelligence, learning, nutritional status and brain development. Neuropsychologia 42, 1118-1131.

5. Ivanovic D, Pérez H, Olivares M, et al. (2004) Scholastic achievement: a multivariate analysis of nutritional, intellectual, socio-economic, socio-cultural, family and demographic variables in Chilean school-age children. Nutrition 2, 878-889.

6. Ivanovic D, Pérez H, Leiva B, et al. (2006) Neuropsychological parameters affecting the Academic Aptitude Test (AAT) achievement at the end of high school in 1996 and their impact on job status in 2002: a multifactorial approach in a follow-up study. In Focus on Neuropsychology Research, pp. 103-140 [JR Dupri, editor]. New York: Nova Science Publishers, Inc.

7. Ivanovic DM, Rodríguez M del P, Pérez HT, et al. (2008) Twelve-year follow-up study of the impact of nutritional status at the onset of elementary school on later educational situation of Chilean school-age children. Eur J Clin Nutr 62, $18-31$.

8. Ivanovic D, Almagia A, Toro T, et al. (2000) Impacto del estado nutricional en el desarrollo cerebral, inteligencia y rendimiento escolar, en el marco de un enfoque multifactorial (Impact of nutritional status on brain development, intelligence and scholastic performance, as part of a multifactorial approach). La Educación (OEA) 44, 3-35.

9. Ivanovic D, Leiva B, Perez H, et al. (2000) Long-term effects of severe undernutrition during the first year of life on brain development and learning in Chilean high school graduates. Nutrition 16, 1056-1063.

10. Ivanovic D, Leiva B, Pérez H, et al. (2002) Nutritional status, brain development and scholastic achievement of Chilean high school graduates from high and low intellectual quotient and socio-economic status. Br J Nutr 87, 81-92.

11. Schiefelbein E \& Farrel J (1982) Eight Years of Their Lives: Through Schooling to the Labour Market in Chile, IDRC, 191e. Otawa: International Development Research Centre.

12. Schiefelbein E \& Simmons J (1981) The Determinants of School Achievement: A Review of the Research for Developing Countries, IDRC-TS 24c. Otawa: International Development Research Centre.

13. Ivanovic R, Forno H, Castro CG, et al. (2000) Intellectual ability and nutritional status assessed through anthropometric measurements of Chilean school-age children from different socio-economic status. Ecol Food Nutr 39, 35-59.

14. Ivanovic D, Forno H \& Ivanovic R (2001) Estudio de la capacidad intelectual (Test de Matrices Progresivas de Raven) en escolares de 5 a 18 años. II. Interrelaciones con factores socioeconómicos, socioculturales, familiares, de exposición a medios de comunicación de masas, demográficos y educacionales (Study of intellectual capacity (Raven's Progressive Matrices Test) in school children 5 to 18 years. II. Interrelationships with socio-economic, socio-cultural, family, exposure to mass media, demographic and educational). Rev Psicol Gen Apl 54, 443-466.

15. Ivanovic D, Ivanovic R \& Middleton S (editors) (1988) Rendimiento Escolar y Estado Nutricional (Educational Achievement and Nutritional Status). Santiago: Universidad de Chile Institute of Nutrition and Food Technology (INTA).

16. Ivanovic R \& Ivanovic D (1990) Características socioeconómicas, socioculturales, familiares y demográficas de estudiantes de Educación Básica y Media (Región Metropolitana de Chile 1986-1987) (Socioeconomic, sociocultural, family and demographic characteristics of students of elementary and high school (Metropolitan Region of Chile 1986-1987)). Rev Sociol 5, 183-201.

17. Ivanovic D, Zacarías I, Saitúa MT, et al. (1988) Educational achievement and nutritional status of elementary and high school graduates. In Dietetics in the 90s. Role of the Dietitian/ Nutritionist, pp. 331-334 [MF Moyal, editor]. London: John Libbey Eurotext Ltd.

18. Broman SH, Nichols L \& Kennedy WW (editors) (1975) Preschool IQ Prenatal and Early Developmental Correlates. New York: Wiley.

19. Edwards LN \& Grossman M (1980) The relationship between children's health and intellectual development. In Health: What is it Worth? Measure of Health Benefits, pp. 273-314 [SJ Mushkin and DW Dunlop, editors]. New York: Pergamon Press.

20. Ivanovic D \& Marambio M (1989) Nutrition and education. I. Educational achievement and anthropometric parameters of Chilean elementary and high school graduates. Nutr Rep Int 39, 983-993.

21. Ishikawa T, Furuyama M, Ishikawa M, et al. (1988) Growth and achievement of large- and small-headed children in a normal population. Brain Dev 10, 295-299.

22. Ivanovic D, Olivares M, Castro C, et al. (1996) Nutrition and learning in Chilean school-age children. Chile's Metropolitan Area Survey 1986-1987. Nutrition 12, 321-328. 
23. Bartholomeusz HH, Courchesne E \& Karns CM (2002) Relationship between head circumference and brain volume in healthy normal toddlers, children, and adults. Neuropediatrics 33, 239-241.

24. Ivanovic D (1996) Does undernutrition during infancy inhibit brain growth and subsequent intellectual ability? (Prospective overview). Nutrition 12, 568-571.

25. Stoch MB, Smythe PM, Moodie AD, et al. (1982) Psychosocial outcome and CT findings after gross undernourishment during infancy: a 20-year developmental study. Dev Med Child Neurol 24, 419-436.

26. Baum JD \& Searls D (1971) Head shape and size of pre-term low-birthweight infants. Dev Med Child Neurol 13, 576-581.

27. Botting N, Powls A, Cooke RW, et al. (1998) Cognitive and educational outcome of very low-birth weight children in early adolescence. Dev Med Child Neurol 40, 652-660.

28. Camp BW, Broman SH, Nichols PL, et al. (1998) Maternal and neonatal risk factors for mental retardation: defining the 'at-risk' child. Early Hum Dev 50, 159-173.

29. Desch LW, Anderson SK \& Snow JH (1990) Relationship of head circumference to measures of school performance. Clin Pediatr 29, 389-392.

30. Dolk H (1991) The predictive value of microcephaly during the first year of life for mental retardation at seven years. Dev Med Child Neurol 33, 974-983.

31. Emond AM, Lira PI, Lima MC, et al. (2006) Development and behaviour of low-birthweight term infants at 8 years in northeast Brazil: a longitudinal study. Acta Paediatr 95, 1249-1257.

32. Fisch RO, Bilek MK, Horrobin JM, et al. (1976) Children with superior intelligence at 7 years of age: a prospective study of the influence of perinatal, medical and socioeconomic factors. Am J Dis Child 130, 481-487.

33. Gale CR, O'Callaghan FJ, Bredow M, et al. (2006) The influence of head growth in fetal life, infancy, and childhood on intelligence at the ages of 4 and 8 years. Pediatrics 118, $1486-1492$.

34. Hack M \& Breslau N (1986) Very low birth weight infants: effects of brain growth during infancy on intelligence quotient at 3 years of age. Pediatrics 77, 196-202.

35. Hack M, Breslau N, Weissman B, et al. (1991) Effect of very low birth weight and subnormal head size on cognitive abilities at school age. $N$ Engl $J$ Med 325, 231-237.

36. Gale CR, O'Callaghan FJ, Godfrey KM, et al. (2004) Critical periods of brain growth and cognitive function in children. Brain 127, 321-329.

37. Johnson FW (1991) Biological factors and psychometric intelligence: a review. Genet Soc Gen Psychol Monogr 117, 313-357.

38. Nelson KB \& Deutschberger J (1970) Head size at one year as a predictor of four-year IQ. Dev Med Child Neurol 12, 487-495.

39. Ounsted M, Moar VA \& Scott A (1988) Head circumference and developmental ability at the age of seven years. Acta Paediatr Scand 77, 374-379.

40. Sells CJ (1977) Microcephaly in a normal school population. Pediatrics 59, 262-265.

41. Sommerfelt K, Markestad T \& Ellertsen B (1998) Neuropsychological performance in low birth weight preschoolers: a population-based, controlled study. Eur J Pediatr 157, 53-58.

42. Stathis SL, O'Callaghan M, Harvey J, et al. (1999) Head circumference in ELBW babies is associated with learning difficulties and cognition but not ADHD in the school-aged child. Dev Med Child Neurol 41, 375-380.

43. Strauss RS \& Dietz WH (1998) Growth and development of term children born with low birth weight: effects of genetic and environmental factors. J Pediatr 133, 67-72.

44. Weinberg WA, Dietz SG, Penick EC, et al. (1974) Intelligence, reading achievement, physical size and social class. A study of
St. Louis Caucasian boys aged 8-0 to $9-6$ years, attending regular schools. J Pediatr 85, 482-489.

45. Willerman L, Schultz R, Rutledge JN, et al. (1991) In vivo brain size and intelligence. Intelligence 15, 223-228.

46. Casey PH, Whiteside-Mansell L, Barrett K, et al. (2006) Impact of prenatal and/or postnatal growth problems in low birth weight preterm infants on school-age outcomes: an 8-year longitudinal evaluation. Pediatrics 118, 1078-1086.

47. Ivanovic D, Ivanovic R, Truffello I, et al. (1989) Nutritional status and educational achievement of elementary first grade Chilean students. Nutr Rep Int 39, 163-175.

48. Guilford JP \& Fruchter B (editors) (1984) Estadística Aplicada a la Psicología y a la Educación (Fundamental Statistics in Psychology and Education). México: McGraw Hill.

49. Chilean Ministerio de Educación Pública (editor) (1987) Estadísticas Educacionales 1987 (Educational Statistics 1987). Santiago: Chilean Ministry of Education (MINEDUC).

50. Universidad de Chile (editor) (1998) Resultados de la Prueba de Aptitud Académica Proceso 1998 (Results of the Academic Aptitude Test Process 1998). Santiago: Universidad de Chile, Departamento de Evaluación, Medición y Registro Educacional (DEMRE).

51. Rickham PP (1964) Human experimentation. Code of Ethics of the World Medical Association Declaration of Helsinki. Br Med $J$ 2, 177.

52. Gibson R (1990) Principles of Nutritional Assessment. Oxford: Oxford University Press.

53. National Center for Health Statistics (2000) Growth Curves. Washington, DC: National Center for Health Statistics Center for Chronic Disease Prevention and Health Promotion.

54. Ivanovic D, Olivares M \& Castro C, et al. (1995) Circunferencia craneana de escolares chilenos de 5 a 18 años. Región Metropolitana de Chile. 1986-1987, 1992 (Head circumference of Chilean schoolchildren from 5 to 18 years. Metropolitan Region of Chile. 1986-1987, 1992). Rev Med Chil 123, 587-599.

55. Nellhaus G (1968) Head circumference from birth to eighteen years. Practical composite international and interracial graphs. Pediatrics 41, 106-114.

56. Roche AF, Mukherjee D \& Guo S, et al. (1987) Head circumference reference data: birth to 18 years. Pediatrics 79, 706-712.

57. Tanner JM (1984) Physical growth and development. In Texbook of Pediatrics, pp. 278-330 [JO Forfar and GC Arneil, editors]. Edinburgh: Churchill Livingstone.

58. Frisancho AR (1981) New norms of upper limb fat and muscle areas for assessment of nutritional status. Am J Clin Nutr 34, 2540-2545.

59. Raven JC (editor) (1957) Test de Matrices Progresivas. Escala Especial (Progessive Matrices Test. Special Scale). Buenos Aires: Piados.

60. Ivanovic R, Forno H, Durán MC, et al. (2003) Estudio de la capacidad intelectual (Test de Matrices Progresivas de Raven) en escolares de 5 a 18 años. I. Antecedentes generales, normas y recomendaciones. Región Metropolitana. Chile. 1986-1987 (Study of intellectual ability (Raven's Progressive Matrices Test) in school children 5 to 18 years. I. General background, rules and recommendations. Metropolitan Region of Chile 1986-1987). Iberpsicología, 8.1.1. (A complete version appeared in Rev Psicol Gen Apl (España) 2000; 53, 5-30).

61. Chile Ministerio de Educación Pública (editor) (1980) Planes y Programas para la Educación General Básica (Plans and Programmes for General Basic Education). Revista de Educación no. 79. Santiago: Ministry of Education (MINEDUC).

62. Alvarez ML, Muzzo S \& Ivanovic D (1985) Escala para medición del nivel socioeconómico en el área de la salud (Scale for measuring socio-economic level in the area of health). Rev Med Chil 113, 243-249. 
63. Ivanovic R \& Sepúlveda O (1988) Rendimiento escolar y exposición a medios de comunicación de masas en estudiantes de enseñanza media del Área Metropolitana (School performance and exposure to mass media for high school students in the Metropolitan Area). Rev Sociol 3, 73-87.

64. SAS Institute, Inc (1983) SAS Introductory Guide. Statistics. Cary, NC: SAS Institute, Inc.

65. Ivanovic R, Castro C \& Ivanovic D (1995) No existe una teoría sobre el rendimiento escolar (There is no theory on school performance). Revista de Educación no. 224, pp. 40-45. Santiago: Ministry of Education (MINEDUC).

66. Downey D (1995) When bigger is not better: family size, parental resources, and children's educational performance. Am Sociol Rev 60, 746-761.

67. Agarwal DK, Awasthy A, Upadilla SK, et al. (1992) Growth, behavior, development and intelligence in rural children between 1-3 years of life. Indian Pediatr 29, 467-480.

68. Casey PH, Barrett K, Bradley RH, et al. (1993) Pediatric clinical assessment of mother-child interaction: concurrent and predictive validity. J Dev Behav Pediatr 14, 313-317.

69. Smith KE, Landry SH, Swank PR, et al. (1996) The relation of medical risk and maternal stimulation with preterm infants' development of cognitive, language and daily living skills. J Child Psychol Psychiatry 37, 855-864.

70. Carter RL, Resnick MB, Ariet M, et al. (1992) A random coefficient growth curve analysis of mental development in low-birth-weight infants. Stat Med 11, 243-256.

71. Duncan GJ, Brooks-Gunn J \& Klebanov PK (1994) Economic deprivation and early childhood development. Child Dev 65, 296-318.

72. Melhuish EC, Lloyd E, Martin S \& Mooney A (1990) Type of childcare at 18 months. II. Relations with cognitive and language development. J Child Psychol Psychiatry 31, 861-870.

73. Sandiford P, Cassel J, Sanchez G, et al. (1997) Does intelligence account for the link between maternal literacy and child survival? Soc Sci Med 45, 1231-1239.

74. Clifton R (1983) Socio-economic status and educational performances: a comparison of students in England and New Zealand. Int J Comp Sociol 24, 187-199.

75. Desai U (1991) Determinants of educational performance in India: role of home and family. Int Rev Educ 37, 245-265.

76. Vera Noriega A, Mejia LA, Saucedo S, et al. (1990) Psychological, nutritional, socio-economic aspects and family relations of Mexican children with low school performance. Arch Latinoam Nutr 40, 475-489.

77. Sciara FJ (1975) Effects of father absence on the educationa achievement of urban black children. Child Stud J 5, 45-55.

78. Crandell LE \& Hobson RP (1999) Individual differences in young children's IQ: a social-developmental perspective. J Child Psychol Psychiatry 40, 455-464.
79. David M (1998) Involvements and investments in education: mothers and schools. J Just Caring Educ 4, 30-46.

80. Juang LP \& Silbereisen RK (2002) The relationship between adolescent academic capability beliefs, parenting and school grades. J Adolesc 25, 3-18.

81. Cassidy T \& Lynn R (1991) Achievement motivation, scholastic achievement, cycles of disadvantage and social competence: some longitudinal data. Br J Educ Psychol 61, 1-12.

82. Rostain AL (1997) Assessing and managing adolescents with school problems. Adolesc Med 8, 57-76.

83. Andreasen NC, Flaum M, Swayze V II, et al. (1993) Intelligence and brain structure in normal individuals. Am J Psychiatry 150, 130-134

84. Pennington BF, Filipek PA, Lefly D, et al. (2000) A twin MRI study of size variations in human brain. J Cogn Neurosci 12, 223-232.

85. Reiss AL, Abrams MT, Singer HS, et al. (1996) Brain development, gender and IQ in children. A volumetric imaging study. Brain 119, 1763-1774.

86. Larroque B, Bertrais S, Czernichow P, et al. (2001) School difficulties in 20-year-olds who were born small for gestational age at term in a regional cohort study. Pediatrics 108, 111-115.

87. Ministerio de Educación Pública (1999) Programa de Mejoramiento de la Calidad de la Educación (MECE), Programa MECE-Educación Superior (MECESUP) 1999-2003 (Program for Improving the Quality of Education (MECE), MECE-Higher Education Program (MECESUP) 1999-2003). Santiago: Ministry of Education (MINEDUC).

88. Ministerio de Educación Pública (2000) Programa de Mejoramiento de la Calidad de la Educación (MECE), Programa MECE-Media (Program for Improving the Quality of Education (MECE), MECE-High School Program). Santiago: Ministry of Education (MINEDUC).

89. Yaqub S (2002) Poor children grow into poor adults: harmful mechanisms or over-deterministic theory? J Int Dev 14, $1081-1093$.

90. Grantham-McGregor S, Cheung YB, Cueto S, et al. (2007) Developmental potential in the first 5 years for children in developing countries. Lancet 369, 60-70.

91. United Nations International Children's Fund (1999) Financing of Education: Effects on Equity. Cycle of Debates: Challenges of the Educational Policy no. 2. Santiago: UNICEF.

92. United Nations International Children's Fund (2000) High School Dropout. Cycle of Debates: Challenges of the Educational Policy no. 1. Santiago: UNICEF.

93. United Nations World Food Program (2006) Towards the Elimination of Chronic Undernutrition in the Andean Region by 2015. Technical Regional Consultation. Agreements. Lima: World Food Program. 